\title{
Physiognomy and structure of a seasonal deciduous forest on the Ibiapaba plateau, Ceará, Brazil ${ }^{1}$
}

\author{
Fisionomia e estrutura de uma floresta estacional decídua no planalto da Ibiapaba, Ceará, Brasil
}

\author{
Jacira Rabelo Lima ${ }^{2}$,Everardo Valadares de Sá Barretto Sampaio ${ }^{3}$, \\ Maria Jesus Nogueira Rodal ${ }^{2}$ \& Francisca Soares Araújo ${ }^{4}$
}

\begin{abstract}
The Brazilian semiarid region is dominated by caatinga. However, other vegetation formations occur, including deciduous and semi-deciduous forests. This study describes physiognomy and structure of a forest on the sedimentary Ibiapaba plateau. All plants within one hectare were separated into three components: woody plants with perimeter at soil level (PSL) $\geq 9 \mathrm{~cm}$ (WCLP), woody plants with PSL $\geq 3$ and $\leq 8.9 \mathrm{~cm}$ (WCSP), and herb/subwoody plants (HSwC). WCLP included 88 species ( 33 families), WCSP 50 species (23 families) and HSwC only 7 species ( 5 families). Total density, basal area, and maximum and average height of WCLP were 5683 plants/ha, $47 \mathrm{~m}^{2} / \mathrm{ha}, 18$ and $5 \mathrm{~m}$ respectively. Total density and basal area of WCSP were 17500 plants $/$ ha and $2.8 \mathrm{~m}^{2} /$ ha, respectively. Density of HSwC was 9 plants $/ \mathrm{m}^{2}$ and only $31 \%$ of the sampled area was occupied by this component.
\end{abstract}

Key words: basal area; dry tropical forest; phytosociology; plant height.

\section{Resumo}

O semi-árido brasileiro é dominado pela caatinga. Entretanto, outras formações vegetacionais são encontradas, por exemplo, as florestas decíduas e semidecíduas. Este estudo descreve a fisionomia e a estrutura de uma floresta estacional no planalto sedimentar da Ibiapaba, Ceará. Foi selecionada uma parcela de um hectare e as plantas separadas em três componentes: plantas lenhosas com perímetro ao nível do solo $\geq 9 \mathrm{~cm}$ (CLS), plantas lenhosas com perímetro $\geq 3 \mathrm{e} \leq 8.9 \mathrm{~cm}$ (CLI), e herbáceas/sublenhosas com perímetro $<3 \mathrm{~cm}$ (HSL). No CLS foram encontradas 88 espécies (33 famílias), no CLI 50 espécies (23 famílias) e no HSL sete espécies (cinco famílias). No CLS, densidade total, área basal e altura máxima e média foram 5683 plantas $/ \mathrm{ha}, 47 \mathrm{~m} / \mathrm{ha}, 18$ e $5 \mathrm{~m}$, respectivamente. No CLI, densidade e área basal foram 17500 plantas/ha e $2,8 \mathrm{~m}^{2} / \mathrm{ha}$. Em HSL, a densidade foi 9 plantas $/ \mathrm{m}^{2}$ e apenas $31 \%$ da área amostrada foi coberta por esse componente.

Palavras-chave: área basal; floresta tropical seca; fitossociologia; altura de planta.

\section{Introduction}

The heterogeneity of the flora and physiognomies of the different vegetations types in the Brazilian semiarid region is caused by two rainfall gradients, one in the South-North and the other in the East-West direction, and by marked geologic differences (Rodal et al. 2008). At higher altitudes, where aridity is less accentuated, the seasonal non-thorny formations occur (Araújo et al. 1998; Araújo et al. 1999; Rodal \& Nascimento 2002; Ferraz et al. 2003; Araújo et al. 2005b). They belong to two physiognomic types: 1) non-forest formations, mainly savanna (cerrado) and closed shrubland (carrasco), on the sedimentary plateaus; and 2) perennial, seasonal forest formations, both on sedimentary and crystalline substrates (Rodal \& Nascimento 2002; Araújo et al. 2005b).

Flora, physiognomy, and structure of these forests are scarcely known (Andrade \& Rodal 2004; Rodal \& Nascimento 2006), especially those occurring on sedimentary plateaus (Andrade \& Rodal 2004). Moreover, there is no published detailed

\footnotetext{
${ }^{1}$ Part of the Master thesis of the first author at Universidade Federal Rural de Pernambuco.

${ }^{2}$ Universidade Federal Rural de Pernambuco, Depto. Biologia, R. Dom Manoel de Medeiros s/n, Dois Irmãos, 52171900, Recife, PE, Brasil.

${ }^{3}$ Universidade Federal de Pernambuco, Depto. Energia Nuclear, Av. Prof. Luís Freire 1000, 50740-540, Recife, PE, Brasil.

${ }^{4}$ Universidade Federal do Ceará, Depto. Biologia, Av. Mister Hull s/n, 60455-760, Fortaleza, CE, Brazil.
} 
description of the vertical organization in these forests which help design projects to manage these forests in order to maintain biological diversity.

The description and classification of plant communities generally focuses on features such as floristic composition, structure and relative species abundances (Box \& Fujiwara 2005). The species have different positions along a vertical gradient of light intensity, occurring one higher than the other to form the community's vertical structure (Whittaker 1975). The vertical differentiation is most pronounced in woody vegetation that has various synusia which may have floristic compositions independent of one another (Maarel 2005). Based on the vertical stratification of the vegetation, it is possible to infer the potential composition of functional groups of different strata. The vegetation can then be managed in order to maintain maximum local biological diversity.

Thus, this work aims to describe physiognomy and structure of three different strata of the seasonal deciduous forest of the Ibiapaba sedimentary plateau, Ceará. We aim to answer the following questions: 1) What are the physiognomy and the structure of this forest? 2) Is this forest structurally similar to other forest formations of the Brazilian semiarid domain or to non-forest formations of other sedimentary areas?

\section{Material and Methods}

\section{Study area}

The study area is located within the 2794 ha of seasonal forest inside the Reserva Natural Serra das Almas, Ceará state, Brazil. The seasonal forest occupies a narrow strip in the upper part of the steep eastern slope on the south-central Ibiapaba plateau, which forms the oriental border of the Middle Northern Sedimentary Basin (Lins 1978). The forest is limited to the west by carrasco vegetation, on top of the plateau, and by caatinga vegetation to the east, on the lower parts of the slope, extending to cover most of the lowlands in Ceará. In the forest area, a one-hectare plot was installed, at an altitude of about $650 \mathrm{~m}$, within the following coordinates $40^{\circ} 54^{\prime} 5^{\prime \prime} \mathrm{W}$ and $5^{\circ} 8^{\prime} 29^{\prime \prime} \mathrm{S}$; $40^{\circ} 54^{\prime} 45^{\prime \prime} \mathrm{W}$ and $5^{\circ} 8^{\prime} 30^{\prime \prime} \mathrm{S}$; 40 ${ }^{\circ} 54^{\prime} 46^{\prime \prime} \mathrm{W}$ and $5^{\circ} 8^{\prime} 36^{\prime \prime} \mathrm{S}$ and $40^{\circ} 54^{\prime} 50^{\prime \prime} \mathrm{W}$ and $5^{\circ} 8^{\prime} 35^{\prime \prime} \mathrm{S}$.

Mean annual rainfall in the study area from 2000 to 2004 was 1044 mm, January to April being the rainiest period, corresponding to more than $80 \%$ of annual precipitation. In general, rainfall was concentrated in a single month and did not occur from July to December. The mean annual temperature during the study year (2004) was $24.8^{\circ} \mathrm{C}$.
The soil was characterized by digging a $1 \times 1 \mathrm{~m}$ trench and collecting samples from the top $10-\mathrm{cm}$ layer and from the layer below down to the parent material (75 cm depth). Physical (Tab. 1) and chemical (Tab. 2) analyses were performed in the Departamento de Ciências do Solo, Universidade Federal do Ceará. The soil was classified as a dystrophic Latosol, poorly developed, with low $\mathrm{pH}$ and low cation exchange capacity (T). In general, $\mathrm{Ca}, \mathrm{Mg}, \mathrm{K}, \mathrm{P}$, organic matter and nitrogen content were low and decreased from the superficial to the subsuperficial layer, while the opposite occurred with $\mathrm{Al}$ content. Texture varied from sandy to sandy loam. Coarse sand, silt and clay content increased with depth, while that of fine sand decreased.

\section{Phytosociological survey}

The plants were divided into three components: a) woody component with large perimeter (WCLP), which comprised all plants with stem perimeter at soil level (PSL) equal to or greater than $9 \mathrm{~cm}$; b) woody component with small perimeter (WCSP), comprising plants with PSL $\geq 3$ and $\leq 8.9 \mathrm{~cm}$; and c) herb/subwoody component (HSwC), comprising plants with green stems, without or with slight lignification in the aerial part and that were up to $1 \mathrm{~m}$ tall and $2.9 \mathrm{~cm}$ perimeter, excluding the young plants of woody species.

The study hectare was divided into plots of different sizes, depending on the component analyzed. WCLP was analyzed in 100 contiguous $10 \times 10 \mathrm{~m}$ plots and WCSP in 50 plots, $2 \times 2 \mathrm{~m}$ each, placed in the right proximal corner of each alternate larger plot. In these two components, the height and PSL of all live plants (except lianas) were measured, following the criteria previously described. HSwC was analyzed in 100 plots $1 \times$ $1 \mathrm{~m}$ each, at the left proximal corner of each of the larger plots, during the rainy season. In $\mathrm{HSwC}$, all plants were identified and the plot area proportion covered by each species was estimated, with the help of a $1 \times 1 \mathrm{~m}$ grid, divided into 100 squares of $0.1 \times 0.1 \mathrm{~m}$. Presence in one of the squares was counted as $1 \%$ coverage. The botanical material was incorporated into the EAC (Prisco Bezerra) herbarium, of the Universidade Federal do Ceará. APG III (2009) classification system was adopted.

The following phytosociological parameters were calculated for WCLP and WCSP: relative density $(\operatorname{ReD}, \%)$, relative frequency $(\mathrm{ReF}, \%)$, relative basal area $(\mathrm{ReBa}, \%)$ and importance 
Table 1 - Particle size analysis of soil samples from the forest seasonal deciduous montane forest of Reserva Natural Serra das Almas, Crateús, Ceará state.

\begin{tabular}{lccccc}
\hline $\operatorname{Depth}(\mathbf{c m})$ & Coarse sand $(\mathbf{g} / \mathbf{k g})$ & Fine sand $(\mathbf{g} / \mathbf{k g})$ & Silt $(\mathbf{g} / \mathbf{k g})$ & Clay $(\mathbf{g} / \mathbf{k g})$ & Texture class \\
\hline 0 to 10 & 130 & 710 & 80 & 80 & Sand \\
11 to 75 & 240 & 510 & 140 & 110 & Loamy sand \\
\hline
\end{tabular}

Table 2 - Chemical analysis of soil samples from the seasonal deciduous montane forest of Reserva Natural Serra das Almas, Crateús, Ceará state.

\begin{tabular}{|c|c|c|c|c|c|c|c|c|c|c|c|c|}
\hline \multirow{2}{*}{$\begin{array}{l}\text { Depth } \\
\text { (cm) }\end{array}$} & \multicolumn{5}{|c|}{ Sorptive Complex } & \multirow{2}{*}{$\begin{array}{c}\mathbf{P} \\
(\mathrm{mg} / \mathrm{kg})\end{array}$} & \multirow{2}{*}{$\begin{array}{c}\mathbf{V} \\
(\%)\end{array}$} & \multirow{2}{*}{$\begin{array}{c}\mathbf{M} \\
(\%)\end{array}$} & \multirow{2}{*}{$\begin{array}{c}\text { C } \\
(\mathrm{g} / \mathrm{kg})\end{array}$} & \multirow{2}{*}{$\begin{array}{c}\mathbf{N} \\
(\mathrm{g} / \mathrm{kg})\end{array}$} & \multirow[t]{2}{*}{ pH } & \multirow{2}{*}{$\begin{array}{c}\mathbf{T} \\
\left(\mathrm{cmol}_{\mathrm{c}} \cdot \mathrm{kg}^{-1}\right)\end{array}$} \\
\hline & $\mathrm{Ca}^{2+}$ & $\begin{array}{l}\mathbf{M g}^{2+} \\
\quad(\mathrm{cm}\end{array}$ & $\begin{array}{c}\mathbf{N a}^{+} \\
\text {olc.kg }\end{array}$ & $\mathbf{K}^{+}$ & $\mathbf{A} \mathbf{l}^{3+}$ & & & & & & & \\
\hline 0 to 10 & 0.9 & 0.9 & 0.1 & 0.09 & 0.85 & 3 & 32 & 30 & 10.6 & 1.1 & 4 & 6.3 \\
\hline 11 to 75 & 0.7 & 0.9 & 0.1 & 0.05 & 1.45 & 1 & 27 & 46 & 6.48 & 0.7 & 4.2 & 6.4 \\
\hline
\end{tabular}

$\mathrm{Ca}^{2+}=$ calcium; $\mathrm{Mg}^{2+}=$ magnesium $; \mathrm{Na}^{+}=$sodium $; \mathrm{K}^{+}=$potassium $; \mathrm{Al}^{3+}=$ aluminum; $\mathrm{P}=$ phosphorus $; \mathrm{V}=$ base saturation; $\mathrm{M}=$ aluminum saturation; $\mathrm{C}=$ carbon; $\mathrm{N}=$ nitrogen; $\mathrm{pH}=$ soil $\mathrm{pH} ; \mathrm{T}=$ cation exchange capacity.

value (IV, \%), using the formulas described by Rodal et al. (1992), and Shannon diversity index, according to Magurran (1988). The calculations were done using FITOPAC (Shepherd 2006).

Aiming to compare WCLP physiognomy and structure of the study area with that of other seasonal forests and non-forest formations within the Brazilian semiarid region (only surveys with inclusion criterion of PSL $\geq 3 \mathrm{~cm}$ ) a table was organized containing information on total plant density, community basal area, maximum plant height, proportion of plants over $8 \mathrm{~m}$ tall, and mean and maximum stem diameters. For each compared site, information on altitude, mean annual rainfall and sample area were also included. Ten areas were included in the comparison, five classified as seasonal forests and five as non-forest formations.

\section{Results}

In the woody component with large perimeter (WCLP), 88 species were found, belonging to 31 families (Tab. 3). The families richest in species were: Fabaceae (19 species), Euphorbiaceae (10), Erythroxylaceae and Myrtaceae (six each). The Shannon diversity index (H') was 3.20 nats/plant. Total density and basal area were 5683 plant/ha and $47 \mathrm{~m}^{2} /$ ha, respectively. Species with the highest IV and relative basal areas were Gymnanthes sp.1, Bauhinia pulchella and
Piptadenia moniliformis, which accounted for $28 \%$ of the total IV (Tab. 3). Gymnanthes sp.1, Bauhinia pulchella and Croton argyrophylloides were the species with the highest absolute frequencies $(99 \% ; 97 \%$ and $84 \%$, respectively).

Maximum and average height were 18 and $5 \mathrm{~m}$ $( \pm 2)$, respectively, and only $11 \%$ of the plants attained heights over $8 \mathrm{~m}$. Maximum and average diameters were 65.2 and $8.4 \mathrm{~cm}$ (6), with $33 \%$ of all plants belonging to the 3 to $6 \mathrm{~cm}$ diameter class and $47 \%$ to the 6 to 9 and 9 to $12 \mathrm{~cm}$ classes. In the same WCLP component, two strata were identified. The lowest stratum was dominated by plants at most $8 \mathrm{~m}$ in height, with a continuous canopy distribution. The most abundant species in this stratum were Gymnanthes sp.1, Bauhinia pulchella, Croton argyrophyloides and Maytenus sp. The upper stratum was dominated by plants up to $12 \mathrm{~m}$ tall but some plants of Brosimum gaudichaudii, Piptadenia moniliformis and Swartzia flaemingii were taller, without forming a continuous canopy. Aspidosperma subincanum, Piptadenia moniliformis, Swartzia flaemingii and Thiloa glaucocarpa were the most frequent species in this upper stratum.

The woody component with small perimeter (WCSP) included 50 species, belonging to 22 families. The families richest in species were: Fabaceae and Euphorbiaceae (eight species each), Erythroxylaceae (four) and Bignoniaceae (three). 
Table 3 - Phytosociological parameters of plants with stem diameters $\geq 9 \mathrm{~cm}$ in the forest of Reserva Natural Serra das Almas, Crateús, Ceará state, in decreasing order of their importance value (IV). $\mathrm{N}$ - number of individuals per hectare; $\mathrm{NP}$ - number of plots where the species was found; ReD - relative density of the species (\%); ReBa - relative basal area of the species (\%); and ReF - relative frequency of the species (\%). Collectors: FSA - Francisca Soares Araújo; JRL - Jacira Rabelo Lima; LWLV - Luis Wilson Lima-Verde; MSS - Melissa S. Sobrinho; and SFV - Sandra Freitas Vasconcelos.

\begin{tabular}{|c|c|c|c|c|c|c|c|c|}
\hline $\mathbf{N}^{0}$ & Species/ Family & Voucher & IV & $\mathbf{N}$ & NP & ReD & ReBa & $\operatorname{ReF}$ \\
\hline 1 & Gymnanthes sp.1 (Euphorbiaceae) & JRL 29 & 50 & 1507 & 99 & 26.52 & 18.2 & 4.88 \\
\hline 2 & Bauhinia pulchella Benth. (Fabaceae) & JRL 45 & 19 & 537 & 97 & 9.45 & 4.45 & 4.78 \\
\hline 3 & Piptadeniamoniliformis Benth. (Fabaceae) & FSA 1298 & 17 & 122 & 70 & 2.15 & 11.1 & 3.45 \\
\hline 4 & Croton argyrophylloides Müll. Arg. (Euphorbiaceae) & FSA 1294 & 15 & 333 & 84 & 5.86 & 4.94 & 4.14 \\
\hline 5 & Maytenus sp. (Celastraceae) & JRL 100 & 12 & 279 & 76 & 4.91 & 3.31 & 3.75 \\
\hline 6 & Thiloa glaucocarpa (Mart.) Eichler(Combretaceae) & LWLV 1050 & 11 & 138 & 57 & 2.43 & 5.36 & 2.81 \\
\hline 7 & Erythroxylum cf. vacciniifolium Mart. (Erythroxylaceae) & JRL 69 & 9.9 & 167 & 73 & 2.94 & 3.37 & 3.6 \\
\hline 8 & Arrabidaea dispar Bureau ex K. Schum. (Bignoniceae) & JRL 20 & 9.6 & 203 & 80 & 3.57 & 2.1 & 3.94 \\
\hline 9 & Aspidosperma discolor A. DC. (Apocynaceae) & JRL 18 & 8.9 & 139 & 55 & 2.45 & 3.72 & 2.71 \\
\hline 10 & Eugenia cf. piauhiensis O. Berg (Myrtaceae) & JRL 62 & 8.1 & 158 & 72 & 2.78 & 1.79 & 3.55 \\
\hline 11 & Swartziaflaemingii Raddi (Fabaceae) & MSS 262 & 7.9 & 99 & 58 & 1.74 & 3.31 & 2.86 \\
\hline 12 & Xylosma ciliatifolia (Clos) Eichler (Salicaceae) & JRL 77 & 7.3 & 189 & 65 & 3.33 & 0.8 & 3.2 \\
\hline 13 & Copaifera martii Hayne (Fabaceae) & JRL 38 & 7.3 & 79 & 51 & 1.39 & 3.41 & 2.51 \\
\hline 14 & Buchenavia capitata (Vahl) Eichler(Combretaceae) & MSS 292 & 7 & 31 & 28 & 0.55 & 5.04 & 1.38 \\
\hline 15 & Eugenia aff. uvalha Cambess. (Myrtaceae) & JRL 73 & 6.7 & 133 & 60 & 2.34 & 1.36 & 2.96 \\
\hline 16 & Alibertia myrciifolia Spruce ex K Schum. (Rubiaceae) & JRL 102 & 6.5 & 115 & 63 & 2.02 & 1.36 & 3.1 \\
\hline 17 & Eugenia aff. dysenterica DC. (Myrtaceae) & FSA 1291 & 6.5 & 94 & 43 & 1.65 & 2.71 & 2.12 \\
\hline 18 & Aspidosperma subincanum Mart. (Apocynaceae) & JRL 17 & 6.1 & 74 & 44 & 1.3 & 2.62 & 2.17 \\
\hline 19 & Combretum leprosum Mart. (Combretaceae) & & 5.1 & 101 & 51 & 1.78 & 0.78 & 2.51 \\
\hline 20 & Ephedranthus pisocarpus R. E. Fr. (Annonaceae) & & 4.6 & 57 & 41 & 1 & 1.6 & 2.02 \\
\hline 21 & Acacia langsdorfii Benth. (Fabaceae) & JRL 40 & 4.6 & 74 & 26 & 1.3 & 2.01 & 1.28 \\
\hline 22 & Brosimum gaudichaudii Trécul. (Moraceae) & Probio 306 & 4.2 & 40 & 33 & 0.7 & 1.84 & 1.63 \\
\hline 23 & Peixotoa jussieuana Mart. ex A. Juss. (Malpighiaceae) & JRL 33 & 3.9 & 74 & 42 & 1.3 & 0.56 & 2.07 \\
\hline 24 & Croton nepetifolius Baill. (Euphorbiaceae) & JRL 28 & 3.8 & 75 & 39 & 1.32 & 0.57 & 1.92 \\
\hline 25 & Dalbergia cearensis Ducke (Fabaceae) & LWLV 1070 & 3.6 & 45 & 34 & 0.79 & 1.1 & 1.68 \\
\hline 26 & Byrsonima gardneriana A. Juss. (Malpighiaceae) & JRL 32 & 3.2 & 43 & 36 & 0.76 & 0.66 & 1.77 \\
\hline 27 & Hymenaea eriogyne Benth. (Fabaceae) & JRL 42 & 3.1 & 42 & 22 & 0.74 & 1.3 & 1.08 \\
\hline 28 & Eugenia aurata O. Berg (Myrtaceae) & JRL 60 & 3 & 46 & 34 & 0.81 & 0.48 & 1.68 \\
\hline 29 & Agonandra brasiliensis Miers (Opiliaceae) & JRL 56 & 2.8 & 31 & 21 & 0.55 & 1.23 & 1.03 \\
\hline 30 & Vitex schaueriana Moldenke(Lamiaceae) & JRL 64 & 2.7 & 32 & 22 & 0.56 & 1.08 & 1.08 \\
\hline 31 & Aspidosperma multiflorum A. DC. (Apocynaceae) & JRL 19 & 2.6 & 19 & 12 & 0.33 & 1.63 & 0.59 \\
\hline 32 & Galipea aff. trifoliata Auble. (Rutaceae) & JRL 36 & 2.3 & 30 & 21 & 0.53 & 0.72 & 1.03 \\
\hline 33 & Guapira graciliflora (Schmidt) Lundell (Nyctaginaceae) & JRL 34 & 2.3 & 31 & 25 & 0.55 & 0.5 & 1.23 \\
\hline 34 & Erythroxylum stipulosum Plowman (Erythroxylaceae) & JRL 86 & 2.3 & 45 & 26 & 0.79 & 0.2 & 1.28 \\
\hline 35 & Manihot palmata Mull. Arg. (Euphorbiaceae) & JRL 26 & 2.2 & 33 & 29 & 0.58 & 0.22 & 1.43 \\
\hline 36 & Ipomoea brasiliana (C. Martius) Meisner (Convolvulaceae) & JRL 25 & 2 & 37 & 24 & 0.65 & 0.18 & 1.18 \\
\hline 37 & Secondontia cf. foliosa A. DC. (Apocynaceae) & JRL 89 & 1.8 & 36 & 21 & 0.63 & 0.17 & 1.03 \\
\hline 38 & Dalbergia sp. (Fabaceae) & JRL 41 & 1.6 & 23 & 16 & 0.4 & 0.45 & 0.79 \\
\hline 39 & Bauhinia sp. (Fabaceae) & JRL 44 & 1.5 & 46 & 10 & 0.81 & 0.23 & 0.49 \\
\hline 40 & Arrabidaea chica (Humb. \& Bonpl.) B. Verl. (Bignoniceae) & JRL 21 & 1.5 & 25 & 19 & 0.44 & 0.11 & 0.94 \\
\hline 41 & Machaerium acutifolium Vogel.(Fabaceae) & JRL 80 & 1.5 & 20 & 16 & 0.35 & 0.33 & 0.79 \\
\hline 42 & Tocoyena formosa (Cham. \& Schltdl.) K. Schum. (Rubiaceae) & JRL 59 & 1.3 & 17 & 14 & 0.3 & 0.32 & 0.69 \\
\hline
\end{tabular}




\begin{tabular}{|c|c|c|c|c|c|c|c|c|}
\hline $\mathbf{N}^{0}$ & Species/Family & Voucher & IV & $\mathbf{N}$ & NP & ReD & ReBa & $\operatorname{ReF}$ \\
\hline 43 & Paullinia cearensis Somner \& Ferrucci (Sapindaceae) & JRL 34 & 1.2 & 20 & 14 & 0.35 & 0.19 & 0.69 \\
\hline 44 & Eugenia punicifolia (Kunth) DC. (Myrtaceae) & JRL 63 & 1 & 16 & 13 & 0.28 & 0.12 & 0.64 \\
\hline 45 & Gymnanthes sp.2 (Euphorbiaceae) & JRL 27 & 0.9 & 16 & 11 & 0.28 & 0.1 & 0.54 \\
\hline 46 & Trigonia nivea Cambess. (Trigoniaceae) & MSS 248 & 0.8 & 13 & 11 & 0.23 & 0.07 & 0.54 \\
\hline 47 & Croton grewioides Baill. (Euphorbiaceae) & JRL 79 & 0.8 & 13 & 10 & 0.23 & 0.11 & 0.49 \\
\hline 48 & Tassadia burchelii E. Fourn. (Apocynaceae) & JRL 13 & 0.8 & 9 & 8 & 0.16 & 0.26 & 0.39 \\
\hline 49 & Turnera blanchetiana Urb. (Turneraceae) & JRL 65 & 0.7 & 12 & 10 & 0.21 & 0.03 & 0.49 \\
\hline 50 & Erythroxylum sp. (Erythroxylaceae) & JRL 87 & 0.7 & 11 & 9 & 0.19 & 0.07 & 0.44 \\
\hline 51 & Cnidoscolus vitifolius (Mill.) Pohl (Euphorbiaceae) & FSA 1309 & 0.7 & 10 & 10 & 0.18 & 0.04 & 0.49 \\
\hline 52 & Ouratea sp. (Nyctaginaceae) & JRL 54 & 0.7 & 7 & 7 & 0.12 & 0.23 & 0.34 \\
\hline 53 & Helicteres heptandra L.B. Sm. (Malvaceae) & JRL 51 & 0.7 & 12 & 8 & 0.21 & 0.05 & 0.39 \\
\hline 54 & Ximenia americana L. (Olacaceae) & JRL 55 & 0.6 & 12 & 6 & 0.21 & 0.11 & 0.3 \\
\hline 55 & Dioclea megacarpa Rolfe (Fabaceae) & JRL 37 & 0.6 & 8 & 8 & 0.14 & 0.08 & 0.39 \\
\hline 56 & Jacaranda jasminoides (Thunb.) Sandwith (Bignoniceae) & JRL 22 & 0.6 & 8 & 8 & 0.14 & 0.03 & 0.39 \\
\hline 57 & Justicia strobilacea (Nees) Lindau (Acanthaceae) & JRL 15 & 0.5 & 7 & 7 & 0.12 & 0.02 & 0.34 \\
\hline 58 & Ouratea cf. parvifolia Engl. (Nyctaginaceae) & JRL 53 & 0.5 & 5 & 5 & 0.09 & 0.14 & 0.25 \\
\hline 59 & Amburana cearensis (Allemão) A. C. Sm. (Fabaceae) & JRL 72 & 0.5 & 5 & 5 & 0.09 & 0.14 & 0.25 \\
\hline 60 & Campomanesia sp. (Myrtaceae) & JRL 61 & 0.5 & 6 & 6 & 0.11 & 0.07 & 0.3 \\
\hline 61 & Paullinia cf. elegans Cambess. (Sapindaceae) & JRL 35 & 0.5 & 6 & 6 & 0.11 & 0.05 & 0.3 \\
\hline 62 & Hymenaea velutina Ducke (Fabaceae) & JRL 43 & 0.4 & 6 & 5 & 0.11 & 0.06 & 0.25 \\
\hline 63 & Gouania sp. (Rhamnaceae) & JRL 58 & 0.4 & 5 & 5 & 0.09 & 0.02 & 0.25 \\
\hline 64 & Rollinia leptopetala R. E. Fr. (Annonaceae) & JRL 78 & 0.4 & 4 & 4 & 0.07 & 0.09 & 0.2 \\
\hline 65 & Erythroxylum bezerrae Plowman (Erythroxylaceae) & JRL 68 & 0.3 & 3 & 3 & 0.05 & 0.09 & 0.15 \\
\hline 66 & Stachyarrhena cf. spicata Hook. F. (Rubiaceae) & JRL 104 & 0.3 & 5 & 3 & 0.09 & 0.05 & 0.15 \\
\hline 67 & Helicteres muscosa Mart. (Malvaceae) & JRL 52 & 0.3 & 4 & 4 & 0.07 & 0.02 & 0.2 \\
\hline 68 & Erythroxylum laetevirens O.E. Schulz (Erythroxylaceae) & JRL 66 & 0.3 & 4 & 4 & 0.07 & 0.01 & 0.2 \\
\hline 69 & Arrabidaea sp. (Bignoniceae) & JRL 107 & 0.3 & 4 & 3 & 0.07 & 0.05 & 0.15 \\
\hline 70 & Lonchocarpus araripensis Benth. (Fabaceae) & JRL 49 & 0.2 & 2 & 2 & 0.04 & 0.11 & 0.1 \\
\hline 71 & Senna cearensis Afran. Fern. (Fabaceae) & JRL 46 & 0.2 & 3 & 3 & 0.05 & 0.01 & 0.15 \\
\hline 72 & Trichilia elegans A. Juss. (Meliaceae) & JRL 31 & 0.2 & 3 & 3 & 0.05 & 0.01 & 0.15 \\
\hline 73 & Rubiaceae & JRL 103 & 0.2 & 4 & 2 & 0.07 & 0.04 & 0.1 \\
\hline 74 & Cochlospermum vitifolium (Willd.) Spreng. (Bixaceae) & SFV 4 & 0.2 & 2 & 1 & 0.04 & 0.1 & 0.05 \\
\hline 75 & Commiphora leptophloeos (Mart.) J.B. Gillett (Burseraceae) & JRL 48 & 0.2 & 2 & 2 & 0.04 & 0.03 & 0.1 \\
\hline 76 & Sapium aff. argutum (Müll. Arg.) Huber (Euphorbiaceae) & JRL 75 & 0.2 & 2 & 2 & 0.04 & 0.02 & 0.1 \\
\hline 77 & Croton blanchetianus Müll. Arg. (Euphorbiaceae) & JRL 82 & 0.1 & 4 & 1 & 0.07 & 0.02 & 0.05 \\
\hline 78 & Tabebuia cf. ochracea (Cham.) Standl. (Bignoniceae) & JRL 23 & 0.1 & 1 & 1 & 0.02 & 0.07 & 0.05 \\
\hline 79 & Luetzelburgia auriculata (Allemão) Ducke (Fabaceae) & JRL 71 & 0.1 & 1 & 1 & 0.02 & 0.05 & 0.05 \\
\hline 80 & Lindackeria ovata (Benth.) Gilg (Achariaceae) & JRL 76 & 0.1 & 1 & 1 & 0.02 & 0.03 & 0.05 \\
\hline 81 & Mimosa sp. (Fabaceae) & JRL 39 & 0.1 & 1 & 1 & 0.02 & 0.02 & 0.05 \\
\hline 82 & Colubrina cordifolia Reissek (Rhamnaceae) & MSS 248 & 0.1 & 1 & 1 & 0.02 & 0.01 & 0.05 \\
\hline 83 & Cordia rufescens A. DC. (Boraginaceae) & JRL 24 & 0.1 & 1 & 1 & 0.02 & 0.01 & 0.05 \\
\hline 84 & Peltogyne confertiflora (Mart. ex Hayne) Benth. (Fabaceae) & JRL 50 & 0.1 & 1 & 1 & 0.02 & 0 & 0.05 \\
\hline 85 & Erythroxylum barbatum O.E. Schulz (Erythroxylaceae) & JRL 67 & 0.1 & 1 & 1 & 0.02 & 0 & 0.05 \\
\hline 86 & $\begin{array}{l}\text { Senna trachypus (Mart. ex Benth.) H.S. Irwin \& Barneby } \\
\text { (Fabaceae) }\end{array}$ & JRL 47 & 0.1 & 1 & 1 & 0.02 & 0 & 0.05 \\
\hline 87 & Bredemeyerafloribunda Willd.(Polygalaceae) & JRL 57 & 0.1 & 1 & 1 & 0.02 & 0 & 0.05 \\
\hline & Croton betaceus Baill. (Euphorbiaceae) & JRL 81 & 0.1 & 1 & 1 & 0.02 & 0 & 0.05 \\
\hline
\end{tabular}


The Shannon diversity index (H') was 3.26 nats/plant. Total density and basal area were 17500 plant/ha and $2.8 \mathrm{~m}^{2} / \mathrm{ha}$, respectively. Maximum and average heights were $5 \mathrm{~m}$ and $1.4 \mathrm{~m}( \pm 0.7)$, respectively, most of the plants being under than $2 \mathrm{~m}$ tall ( $83 \%)$ and less than $1.6 \mathrm{~cm}$ diameter $(70 \%)$. Species with the highest IV were Lantana sp., Xylosma ciliatifolium and Croton argyrophylloides, which accounted for $32 \%$ of the total IV (Tab. 4). Cranocarpus gracilis, Lantana cf. brasiliensis, Lantana sp., Justicia fragilis and Wedelia villosa were exclusive to this component.

The herb/subwoody component (HSwC) had only seven species, belonging to 5 families (Tab. 5), excluding saplings and seedlings of species that reach larger sizes. The families Poaceae and Bromeliaceae had higher species richness for this component (two species each). The Shannon diversity index $\left(\mathrm{H}^{\prime}\right)$ was 1.16 nats/plant. Density was 9 plants $/ \mathrm{m}^{2}$ and only $33 \%$ of the sample area was occupied by this component. Most of the plants (63\%) belonged to three species (Streptostachys asperifolia, Pavonia sp. and Scaphispatha hastifolia), which, together with Bromelia auriculata, accounted for most of the plant coverage of this component.

\section{Discussion}

Serra das Almas forest is physiognomically distinct from other seasonal montane forests and also from all non-forest formations already described in Northeast Brazil. In general, seasonal montane forests are physiognomically more variable than rain forests, varying from tall forests to low scrub (Pennington et al. 2009). Density of the most conspicuous component, trees and shrubs with large perimeters (WCLP), was higher than those of the other forests (Tab. 6), except one located at $1100 \mathrm{~m}$ in a crystalline mountain in Serra Talhada, Pernambuco (Ferraz et al. 2003), but lower than those of non-forest formations, especially carrasco (Araújo et al. 1998; Araújo \& Martins 1999).

Basal area, on the contrary, was lower than that of other forests, except for basal area at $900 \mathrm{~m}$ in Serra Talhada, but higher than that of non-forest formations. Considering that basal area is a product of density and stem diameter, the average stem diameter in Serra das Almas is smaller than that of the other forests but greater than that of the nonforest formations. The tallest registered tree, in all compared areas, was found in Serra das Almas but the proportion of trees over $8 \mathrm{~m}$ tall was lower than that of the other forests, except Serra Talhada, but higher than that of the non-forest formations.

In Serra das Almas two distinct strata are distinguished, as has been registered for Neotropical deciduous forests elsewhere (e.g., Murphy \& Lugo 1986), that are essentially tree-dominated with a more-or-less continuous canopy and in which grasses are a minor element (Mooney et al. 1995). In non-forest formations in Northeast Brazil, especially closed shrubland (carrasco), only one stratum is recognized. The presence of scattered very tall trees emerging above the upper stratum distinguishes Serra das Almas from other deciduous forests in the region.

The woody vines formed a considerable proportion of the WCLP species, with 13 species $(16 \%)$, distributed in nine families, corroborating Gentry's statement $(1982,1995)$ that vines are an important component in Neotropical seasonal forests, where they represent about $20 \%$ of the species.

Some of the highest IV species, in the WCLP, in Serra das Almas (Arrabidaea dispar, Croton argyrophylloides, Piptadenia moniliformis, Rollinia leptopetala and Thiloa glaucocarpa) are also important species in Northeastern non-forest formations (Oliveira $e t$ al. 1997; Araújo et al. 1998; Araújo et al. 1999), mainly those on the Middle Northern Sedimentary Basin, which extends for a large area west of the Serra das Almas location. Other important species, like Aspidosperma discolor, A. subincanum and Brosimum gaudichaudii, although present in these non-forest formations, occur with much lower densities.

On the other hand, many of the important species present in these formations were not found in the Serra das Almas forest. In spite of these differences, the flora of the Serra das Almas forest is relatively similar to that of the non-forest formations while it is very different from that of all other deciduous montane forests studied, with which it shares only a few species, none of them with high IV either in Serra das Almas or in those forests (Lima et al. 2009).

Comparisons of the other two plant components, the woody component with small perimeter (WCSP) and the herb/subwoody component (HSwC), with those of other Northeastern formations are difficult to make because of the scarcity of these measurements, 
Table 4 - Phytosociological parameters of plants with stem diameters $>3 \mathrm{~cm}$ and $<9 \mathrm{~cm}$ in the forest of Reserva Natural Serra das Almas, Crateús, Ceará state, in decreasing order of their importance value (IV). N - number of individuals per hectare; NP - number of plots where the species was found; ReD - relative density of the species (\%); $\mathrm{ReBa}$ - relative basal area of the species (\%); and ReF - relative frequency of the species (\%). Collectors: FSA Francisca Soares Araújo; JRL - Jacira Rabelo Lima; LWLV - Luis Wilson Lima-Verde; MSS - Melissa S. Sobrinho; and SFV - Sandra Freitas Vasconcelos.

\begin{tabular}{|c|c|c|c|c|c|c|c|c|}
\hline No & Species/ Family & Voucher & IV & $\mathbf{N}$ & NP & ReD & ReBa & ReF \\
\hline 1 & Lantana sp.(Verbenaceae) & JRL 109 & 46.45 & 52 & 29 & 14.86 & 19.09 & 12.5 \\
\hline 2 & Xylosma ciliatifolia(Clos) Eichler(Salicaceae) & JRL 77 & 24.86 & 30 & 15 & 8.57 & 9.82 & 6.47 \\
\hline 3 & Croton argyrophylloides Müll Arg. (Euphorbiaceae) & FSA 1294 & 23.87 & 31 & 13 & 8.86 & 9.41 & 5.6 \\
\hline 4 & Cranocarpus gracilis A. Fernandes \& P. Bezerra (Fabaceae) & JRL 84 & 21.02 & 28 & 16 & 8 & 6.12 & 6.9 \\
\hline 5 & Gymnanthes sp.1 (Euphorbiaceae) & JRL 29 & 19.13 & 28 & 13 & 8 & 5.53 & 5.6 \\
\hline 6 & Justicia strobilacea (Nees) Lindau (Acanthaceae) & JRL 22 & 13.53 & 15 & 9 & 4.29 & 5.37 & 3.88 \\
\hline 7 & Croton betaceus Baill.(Euphorbiaceae) & JRL 81 & 11.64 & 12 & 11 & 3.43 & 3.47 & 4.74 \\
\hline 8 & Wedelia villosa Gardner. (Asteraceae) & JRL 85 & 8.23 & 12 & 7 & 3.43 & 1.79 & 3.02 \\
\hline 9 & Alibertia myrciifolia Spruce ex K Schum. (Rubiaceae) & JRL 102 & 7.75 & 8 & 8 & 2.29 & 2.01 & 3.45 \\
\hline 10 & Crotonnepetifolius Baill. (Euphorbiaceae) & JRL 28 & 7.65 & 8 & 8 & 2.29 & 1.92 & 3.45 \\
\hline 11 & Evolvulus macroblepharis Meisn. (Convolvulaceae) & JRL 83 & 7.54 & 9 & 8 & 2.57 & 1.52 & 3.45 \\
\hline 12 & Bauhinia pulchella Benth.(Fabaceae) & JRL 45 & 7.24 & 8 & 8 & 2.29 & 1.51 & 3.45 \\
\hline 13 & Arrabidaea dispar Bureau ex K. Schum. (Bignoniaceae) & JRL 20 & 6.32 & 7 & 6 & 2 & 1.73 & 2.59 \\
\hline 14 & Helicteres heptandra L.B. Sm. (Malvaceae) & JRL 51 & 5.85 & 6 & 6 & 1.71 & 1.55 & 2.59 \\
\hline 15 & Justicia fragilis Wall. ex Clarke (Acanthaceae) & JRL 25 & 5.42 & 8 & 1 & 2.29 & 2.7 & 0.43 \\
\hline 16 & Vitex schaueriana Moldenke (Lamiaceae) & JRL 64 & 5.05 & 5 & 4 & 1.43 & 1.9 & 1.72 \\
\hline 17 & Banisteriopsis cf. stellaris (Griseb.) B. Gattes (Malpighiaceae) & JRL 101 & 4.93 & 5 & 4 & 1.43 & 1.78 & 1.72 \\
\hline 18 & Eugenia aff. uvalha Cambess. (Myrtaceae) & JRL 73 & 4.83 & 4 & 4 & 1.14 & 1.97 & 1.72 \\
\hline 19 & Lantana aff. brasiliensis Link(Verbenaceae) & JRL 108 & 4.61 & 5 & 4 & 1.43 & 1.46 & 1.72 \\
\hline 20 & Turnera blanchetiana Urban. (Turneraceae) & JRL 65 & 4.61 & 5 & 5 & 1.43 & 1.03 & 2.16 \\
\hline 21 & Bauhinia sp. (Fabaceae) & JRL 44 & 4.47 & 7 & 2 & 2 & 1.61 & 0.86 \\
\hline 22 & Maytenus sp. (Celastraceae) & JRL 100 & 4.36 & 4 & 3 & 1.14 & 1.92 & 1.29 \\
\hline 23 & Dalbergia sp.(Fabaceae) & JRL 41 & 4 & 4 & 3 & 1.14 & 1.57 & 1.29 \\
\hline 24 & Guapira graciliflora (Schmidt) Lundell (Nyctaginaceae) & JRL 34 & 3.88 & 3 & 3 & 0.86 & 1.72 & 1.29 \\
\hline 25 & Ipomoea brasiliana (C. Martius) Meisner (Convolvulaceae) & JRL 42 & 3.63 & 4 & 4 & 1.14 & 0.76 & 1.72 \\
\hline 26 & Helicteres muscosa Mart. (Malvaceae) & JRL 52 & 3.38 & 4 & 3 & 1.14 & 0.95 & 1.29 \\
\hline 27 & Peixotoa jussieuana Juss. (Malpighiaceae) & JRL 33 & 3.11 & 3 & 3 & 0.86 & 0.96 & 1.29 \\
\hline 28 & Machaerium acutifolium Vogel.(Fabaceae) & JRL 80 & 2.93 & 3 & 3 & 0.86 & 0.78 & 1.29 \\
\hline 29 & Manihot palmata Mull. Arg. (Euphorbiaceae) & JRL 26 & 2.25 & 2 & 2 & 0.57 & 0.82 & 0.86 \\
\hline 30 & Erythroxylum laetevirens O.E. Schulz (Erythroxylaceae) & JRL 66 & 2.24 & 3 & 2 & 0.86 & 0.52 & 0.86 \\
\hline 31 & Dalbergia cearensis Ducke (Fabaceae) & LWLV 1070 & 1.94 & 2 & 2 & 0.57 & 0.51 & 0.86 \\
\hline 32 & Jacaranda jasminoides (Thunb.) Sandwith (Bignoniaceae) & JRL 43 & 1.94 & 2 & 2 & 0.57 & 0.51 & 0.86 \\
\hline 33 & Croton grewioides Baill. (Euphorbiaceae) & JRL 79 & 1.91 & 2 & 2 & 0.57 & 0.48 & 0.86 \\
\hline 34 & Erythroxylum stipulosum Plowman (Erythroxylaceae) & JRL 86 & 1.78 & 2 & 2 & 0.57 & 0.35 & 0.86 \\
\hline 35 & Erythroxylum cf. vacciniifolium Mart. (Erythroxylaceae) & JRL 69 & 1.78 & 2 & 2 & 0.57 & 0.34 & 0.86 \\
\hline 36 & Aspidosperma subicanum Mart. (Apocynaceae) & JRL 17 & 1.62 & 1 & 1 & 0.29 & 0.9 & 0.43 \\
\hline 37 & Gymnanthes sp2 (Euphorbiaceae) & JRL 27 & 1.3 & 2 & 1 & 0.57 & 0.3 & 0.43 \\
\hline 38 & Arrabidaea sp. (Bignoniaceae) & JRL 107 & 1.25 & 2 & 1 & 0.57 & 0.25 & 0.43 \\
\hline
\end{tabular}




\begin{tabular}{lllllllll}
\hline No & Species/ Family & Voucher & IV & N & NP & ReD & ReBa & ReF \\
\hline 39 & Agonandra brasiliensis Miers (Opiliaceae) & JRL 56 & 1.22 & 1 & 1 & 0.29 & 0.51 & 0.43 \\
40 & Eugenia cf. piauhiensis O. Berg (Myrtaceae) & JRL 62 & 1.22 & 1 & 1 & 0.29 & 0.51 & 0.43 \\
41 & Secondontia cf. foliosa A. DC. (Apocynaceae) & JRL 89 & 1.22 & 1 & 1 & 0.29 & 0.51 & 0.43 \\
42 & Erythroxylum sp. (Erythroxylaceae) & JRL 87 & 1.07 & 1 & 1 & 0.29 & 0.35 & 0.43 \\
43 & Senna cearensis Afran. Fern. (Fabaceae) & JRL 46 & 1 & 1 & 1 & 0.29 & 0.28 & 0.43 \\
44 & Piptadenia moniliformis Benth. (Fabaceae) & FSA 1298 & 0.89 & 1 & 1 & 0.29 & 0.17 & 0.43 \\
45 & Lindackeria ovata (Benth) Gilg (Achariaceae) & JRL 76 & 0.84 & 1 & 1 & 0.29 & 0.13 & 0.43 \\
46 & Sapium aff. argutum (Müll. Arg.) Huber (Euphorbiaceae) & JRL 75 & 0.84 & 1 & 1 & 0.29 & 0.13 & 0.43 \\
47 & Tocoyena formosa (Cham. \& Schltdl.) K. Schum. (Rubiaceae) & JRL 59 & 0.84 & 1 & 1 & 0.29 & 0.13 & 0.43 \\
48 & Thiloa glaucocarpa (Mart.) Eichler (Combretaceae) & LWLV 1050 & 0.84 & 1 & 1 & 0.29 & 0.13 & 0.43 \\
49 & Ouratea sp. (Nyctaginaceae) & JRL 54 & 0.84 & 1 & 1 & 0.29 & 0.13 & 0.43 \\
50 & Cordia rufescens A. DC. (Boraginaceae) & JRL 24 & 0.84 & 1 & 1 & 0.29 & 0.13 & 0.43 \\
\hline
\end{tabular}

Table 5 - Families and species of herb and subwoody plants in the forest of Reseva Natural Serra das Almas, Crateús, Ceará state, with their respective proportions of ground cover and densities. Collectors: FSA - Francisca Soares Araújo, JRL - Jacira Rabelo Lima, LWLV - Luis Wilson Lima-Verde.

\begin{tabular}{|c|c|c|c|}
\hline Family / species & Cover \% & Density plant in $100 \mathrm{~m}^{2}$ & Voucher \\
\hline \multicolumn{4}{|l|}{ Araceae } \\
\hline Scaphispatha hastifolia Hook. & 1 & 58 & FSA 1379 \\
\hline \multicolumn{4}{|l|}{ Bromeliaceae } \\
\hline Bromelia plumieri (E. Morren) L.B. Sm. & 1 & 0 & LWLV 982 \\
\hline Bromelia auriculata L.B. Sm. & 8 & 79 & LWLV 1222 \\
\hline \multicolumn{4}{|l|}{ Cyperaceae } \\
\hline Cyperus agregatus (Willd.) Endl. & 1 & 8 & JRL 106 \\
\hline \multicolumn{4}{|l|}{ Malvaceae } \\
\hline Pavonia sp. & 3 & 168 & JRL 90 \\
\hline \multicolumn{4}{|l|}{ Poaceae } \\
\hline Lasiacis cf. sorghoidea (Desv. ex Ham.) Hitchc. \& Chase & 1 & 33 & FSA 1378 \\
\hline Streptostachys asperifolia (Kuntw.) Desv. & 18 & 580 & FSA 1307 \\
\hline
\end{tabular}

coupled with differences in methodology. One of these studies, including WCSP, was conducted in the same place as our study and also in Curimataú (PB), and Betânia (PE) (Araújo et al. 2005a). However, the sampling method was the point quarter method, contrary to the plot method in our study, making it difficult to compare results. Differences shown by the two methods for Serra da Almas (Tab. 7) illustrate this dificulty.

The openness of the canopy in seasonal montane forests allows not only the establishment but also the maintenance of the WCSP (Quigley \& Platt 2003), even outside gaps (Whittaker 1975; Gentry \& Dodson 1987). The WCSP component has usually been ignored in vegetation studies in the region. In fact, its contribution to the basal area is small and it has little value in surveys directed to estimate fuel wood or timber availability. Floristic surveys usually consider that the plants in this component are merely young individuals of species which are also present in the larger component (WCLP). This occurs in forests elsewhere (Whittaker 1975; Quigley \& Platt 2003). However, one family (Asteraceae) was exclusive and another one (Verbenaceae) had most of its representatives in this component, including some exclusive species (Lantana cf. brasiliensis and Lantana sp.). Therefore, inclusion 
Table 6 - Altitude (Alt), mean annual rainfall (MAR), sampled area; total plant density (TPD), community basal area $(\mathrm{CBA})$, maximum plant height $(\mathrm{MxH})$, proportion of plants above $8 \mathrm{~m}$ height $(>8)$, and mean $(\mathrm{MD})$ and maximum stem diameters $(\mathrm{MxD})$ of forest and non forest formations in semiarid Northeast Brazil (only surveys with inclusion criterion of PSL $\geq 3 \mathrm{~cm}$ ).

\begin{tabular}{|c|c|c|c|c|c|c|c|c|c|c|}
\hline Location & $\begin{array}{l}\text { Alt. } \\
\text { (m) }\end{array}$ & $\begin{array}{l}\text { MAR } \\
(\mathrm{mm})\end{array}$ & $\begin{array}{l}\text { Area } \\
\text { (ha) }\end{array}$ & $\begin{array}{l}\text { TPD } \\
(\mathrm{pl} / \mathrm{ha})\end{array}$ & $\begin{array}{c}\text { CBA } \\
\left(\mathrm{m}^{2} / \mathrm{ha}\right)\end{array}$ & $\begin{array}{c}\text { MxH } \\
(\mathrm{m})\end{array}$ & $\begin{array}{r}\mathbf{H}>\mathbf{8} \\
(\%)\end{array}$ & $\begin{array}{l}\text { MD } \\
(\mathrm{cm})\end{array}$ & $\begin{array}{l}\text { MxD } \\
(\mathrm{cm})\end{array}$ & References \\
\hline \multicolumn{11}{|c|}{ Forest formations } \\
\hline Serra das Almas, CE & 650 & 1044 & 1 & 5683 & 47.0 & 18 & 11 & 8.4 & 65 & This study \\
\hline Triunfo 1, PE & 1100 & 1260 & 0.2 & 6515 & 56.7 & 14 & 8 & 8.1 & 102 & Ferraz et al. 2003 \\
\hline Triunfo 2, PE & 900 & 1066 & 0.1 & 3060 & 46.7 & 15 & 12 & 10.5 & 60 & Ferraz et al. 2003 \\
\hline Pesqueira, PE & 1082 & 681 & 0.3 & 4910 & 67.2 & 16 & 21 & 9.8 & 72 & Correia 1996 \\
\hline Jataúba, PE & $1020-1120$ & 764 & 0.3 & 4406 & 49.6 & 15 & 12 & 8.7 & 80 & Moura 1997 \\
\hline Serra de Bodopitá, PB & - & 500 & 0.2 & 3165 & 31.28 & - & - & - & - & Oliveira et al. 2009 \\
\hline Serra de Bodocongó, PB & - & 500 & 0.2 & 3010 & 33.19 & - & - & - & - & Oliveira et al. 2009 \\
\hline Serra do Monte, PB & - & 500 & 0.2 & 4530 & 33.19 & - & - & - & - & Oliveira et al. 2009 \\
\hline Serra do Canoió, PB & - & 500 & 0.2 & 4145 & 23.25 & - & - & - & - & Oliveira et al. 2009 \\
\hline \multicolumn{11}{|c|}{ Non forest formations } \\
\hline Padre Marcos, PI & 420 & 637 & 0.45 & 4618 & 24.2 & 9 & $<1$ & 8.1 & 48 & Oliveira et al. 1997 \\
\hline Baixa Fria, CE & $750-760$ & 838 & 0.25 & 5952 & 14.2 & 8 & 10 & 5.0 & 29 & Araújo et al. 1998 \\
\hline Carrasco, CE & $750-760$ & 838 & 0.25 & 5722 & 26.8 & 13 & 9 & 6.5 & 40 & Araújo et al. 1998 \\
\hline Estrondo, CE & $750-760$ & 838 & 0.25 & 6596 & 19.5 & 11 & $<1$ & 5.4 & 27 & Araújo et al. 1998 \\
\hline Capivara, PI & 600 & 680 & 1 & 5827 & 31.9 & - & - & - & - & Lemos \& Rodal 2002 \\
\hline
\end{tabular}

Table 7-Results obtained with the plot and the quarter point methods for the wood component of small perimeters $(\geq 3 \mathrm{~cm}$ and $\leq 8.9 \mathrm{~cm})$ in the same area of the seasonal deciduous forest of Serra das Almas, Ceará.

\begin{tabular}{lcc}
\hline & Plot & Quarter point \\
\hline Number of families & 22 & 6 \\
Number of species & 50 & 8 \\
Shannon Index (nats/plant) & 3.26 & 1.403 \\
Absolute density (plant/ha) & 17500 & 3423 \\
Basal area $\left(\mathrm{m}^{2} / \mathrm{ha}\right)$ & 2.8 & 0.002 \\
Mean stem diameter $(\mathrm{cm})$ & 1.4 & 0.53 \\
\hline
\end{tabular}

of this component is recommended in future studies in the region.

Density in this component of the forest was quite high, three times higher than that of the larger trees and shrubs (WCLP), but its contribution to basal area was rather small, slightly above $5 \%$ of the basal area of the larger tree and shrub component. The high density of the WCSP component entangled the vegetation, rendering it difficult to penetrate. Together with the influence of the WCLP component, it probably contributed to the suppression of the herb/subwoody component, through light, water and nutrient competition. Density $\left(9\right.$ plants $\left./ \mathrm{m}^{2}\right)$ and soil coverage $(30 \%)$ in this herb/subwoody component were low, as usually reported for other forests (Richard 1996). Within the Brazilian Northeast region, many recent measurements of this component in caatinga areas found much higher densities, from 16 to 1587 plants $/ \mathrm{m}^{2}$ (Barbosa et al. 2005; Reis et al. 2006). 
The larger size (height and diameter) of plants in Serra das Almas than in the non forest formations may result from greater water availability. Nonforest sites tend to have less annual rainfall than Serra das Almas and the topographic position favors the forest in Serra das Almas. Most of the carrasco sites are on top of the flat plateau and their deep, very sandy soil retains little moisture after rain events. Some of the infiltrated water seeps to the slope position where the forest is located. In fact, there is a natural fountain in the forest area but far from the study site, which was chosen to avoid its influence. Many other fountains punctuate the hundreds-of-kilometers long eastern slope of the Ibiapaba plateau and a few of them are still surrounded by forests, but unfortunately most of these forests have small and decreasing areas and only two are in protected reserves.

Mean annual rainfall is not a differentiating factor among the compared montane forests. Rainfall ranges from lower to higher than that at Serra das Almas and the structure of these forests follows no systematic trend in relation to rainfall. Rainfall distribution over the year may be as important or even more important than total annual rainfall (Murphy \& Lugo 1986). Rainfall tends to be more evenly distributed closer to the coast (Pesqueira and Jataúba) than further away (Serra Talhada and Serra das Almas). This may explain the higher similarity in structure of Serra Talhada and Serra das Almas forests which are close but still hundreds of kilometers away, although other factors may be involved. Both Serra Talhada forests are small remnants of only a few hectares and have been disturbed to a higher degree than the remaining forests. The absence of taller trees in both Serra Talhada forests may result from selective cutting. Local information refers to the previous presence of much larger trees in the region. The high density of small plants at the $1100 \mathrm{~m}$ site may reflect regrowth in the openings left after cutting of larger trees.

Thus, it is possible to conclude that Serra das Almas forest is physiognomically distinct form the other seasonal montane forests and also from all non-forest formations analyzed in Northeast Brazil. The vegetation structure at Serra das Almas is in an intermediate position between the forests and the non-forest formations. It has a great abundance of tall, thin trees and shrubs, compared to the relative openness of the also tall but larger stemmed trees in the forests and the higher abundance of smaller trees and shrubs in the non forest formations.

\section{Acknowledgments}

The authors thank the Coordenação de Aperfeiçoamento de Pessoal de Nível Superior (CAPES), for the scholarship, and the Conselho Nacional de Pesquisa (CNPq), for financing the project (Edital Universal, processo 476285/2003-8). We also thank the Associação Caatinga for infrastructure in the field work.

\section{References}

Andrade, K.V.S.A \& Rodal, M.J.N. 2004. Fisionomia e estrutura de um remanescente de floresta estacional semidecídua de terras baixas no Nordeste do Brasil. Revista Brasileira de Botânica 27: 463-474.

APG - Angiosperm Phylogeny Group. 2009. An update of the Angiosperm Phylogeny Group classification for the orders and families of flowering plants: APG III. Botanical Journal of the Linnean Society 161: 105-121.

Araújo, F.S.; Sampaio, E.V.S.B. \& Rodal, M.J.N. 1998. Organização comunitária do componente lenhoso de três áreas de carrasco em Novo Oriente/CE. Revista Brasileira de Biologia 58: 85-95.

Araújo, F.S.; Martins, F.R. \& Shepherd, G.J. 1999. Variações estruturais e florísticas do carrasco no planalto da Ibiapaba, estado do Ceará. Revista Brasileira de Biologia 59: 663-678.

Araújo, F.S.; Rodal, M.J.N.; Barbosa, M.R.V. \& Martins, F.R. 2005b. Repartição da flora lenhosa no domínio da Caatinga. In: Araújo, F.S.; Rodal, M.J.N. \& Barbosa, M.R.V. (orgs.). Análise das variações da biodiversidade do bioma caatinga: suporte a estratégias regionais de conservação. Ministério do Meio Ambiente, Brasília. Pp. 17-35.

Araújo, F.S.; Rodal, M.J.N. \& Barbosa, M.R.V. 2005a. Análise das variações da biodiversidade do bioma caatinga: suporte a estratégias regionais de conservação. Ministério do Meio Ambiente, Brasília. 445p.

Barbosa, M.R.V.; Lima, R.B.; Agra, M.F.; Cunha, J.P. \& Pessoa, M.C.R. 2005. Vegetação e flora fanerogâmica do Curimataú, Paraíba. In: Araújo, F.S.; Rodal, M.J.N. \& Barbosa, M.R.V. (orgs.). Análise das variações da biodiversidade do bioma caatinga: suporte a estratégias regionais de conservação. Ministério do Meio Ambiente, Brasília. Pp. 121-138.

Box, E.O. \& Fujiwara, K. 2005. Vegetation types and their broad-scale distribution. In: van der Maarel, E. (ed.). Vegetation ecology. Blackwell Publishing, Oxford. Pp. 106-128.

Correia, M.S. 1996. Estrutura da vegetação da mata serrana de um brejo de altitude em Pesqueira - PE. Dissertação de Mestrado. Universidade Federal de Pernambuco, Recife. 89p. 
Ferraz, E.M.N.; Rodal, M.J.N. \& Sampaio, E.V.S.B. 2003. Physiognomy and structure of vegetation along an altitudinal gradient in the semi-arid region of Northeastern Brazil. Phytocoenologia 33: 71-92.

Gentry, A.H. 1982. Patterns of neotropical plant species diversity. Evolution Biological 15: 1-84.

Gentry, A.H. 1995. Diversity and floristic composition of neotropical forest. In: Bullock, S.H.; Mooney, H.A. \& Medina, E. (eds.). Seasonally dry tropical forest. Cambridge University Press. Cambridge. Pp. 146-194.

Gentry, A.H. \& Dodson, C.H. 1987. Diversity and biogeography of neotropical vascular epiphytes. Annals of the Missouri Botanical Garden 74: 205-233.

Lemos, J.R. \& Rodal, M.J.N. 2002. Fitossociologia do componente lenhoso de um trecho da vegetação de caatinga no Parque Nacional da Serra da Capivara, Piauí, Brasil. Acta Botanica Brasilica 16: 23-42.

Lima, J.R.; Sampaio, E.V.S.B. Rodal, M.J.N. \& Araújo, F.S. 2009. Composição florística da floresta estacional decídua montana da Serra das Almas, Ceará, Brasil. Acta Botanica Brasilica 23: 756-763.

Lins, R.C. 1978. A bacia do Parnaíba: aspectos fisiográficos. Instituto Joaquim Nabuco de Pesquisas Sociais, Recife. 65p.

Maarel, E.V.D. 2005. Vegetation ecology- an overview. In: Vegetation ecology. Blackwell Publishing, Malden. Pp. 1-51.

Magurran, A.E. 1988. Ecological diversity and its measurement. Cambridge University Press, Cambridge. 177p.

Mooney, H.A.; Bullock, S.H. \& Medina, E. 1995. In: Bullock, S.H.; Mooney, H.A. \& Medina, E. (eds.). Seasonally dry tropical forest. Cambridge University Press Cambridge. Pp. 1-9.

Moura, F.B.P. 1997. Fitossociologia de uma mata serrana semidecídua no brejo de Jataúba, Pernambuco, Brasil. Dissertação de Mestrado. Universidade Federal de Pernambuco, Recife. 260p.

Murphy, P.G. \& Lugo, A.E. 1986. Ecology of tropical dry forest. Annual Review of Ecology and Systematics 17: 67-88.

Oliveira, M.E.A.; Sampaio, E.V.S.B.; Castro, A.A.J.F. \& Rodal, M.J.N. 1997. Flora e fitossociologia de uma área de transição carrasco-caatinga de areia em Padre Marcos, Piauí. Naturalia 22: 131-150.

Oliveira, P.T.B.; Trovão, D.M.B.M.; Carvalho, E.C.D.C.; Souza, B.C. \& Ferreira, L.M.R. 2009. Florística e fitossociologia de quatro remanescentes vegetacionais em áreas de serra no Cariri paraibano. Revista Caatinga 22: 169-178.

Pennington, R.T.; Lavin, M. \& Oliveira-Filho, A.T. 2009. Woody plant diversity, evolution and ecology in the tropics: perspectives from seasonally dry tropical forests. Annual Review of Ecology, Evolution, and Systematics 40: 437-57.

Quigley, M.F. \& Platt, W.J. 2003. Composition and structure of seasonally deciduos forests in the Americas. Ecological Monographs 73: 87-106.

Reis, A.M.S.; Araújo, E.L.; Ferraz, E.M.N. \& Moura, A.N. 2006. Inter-annual variations in the population structure of an herbaceous of caatinga vegetation in Pernambuco, Brazil. Revista Brasileira de Botânica 29: 497-508.

Richards, P.W. 1996. The tropical rain forest: an ecological study. Cambridge University Press, Cambridge. 575p.

Rodal, M. J.N.; Barbosa, M.R.V. \& Thomas, W.W. 2008. Do the seasonal forests in Northeastern Brazil represent a single floristic unit? Brazilian Journal of Biology 68: 631-637.

Rodal, M.J.N. \& Nascimento, L.M. 2006. The arboreal component of a dry forest in Northeastern Brazil. Brazilian Journal of Biology 66: 479-491.

Rodal, M.J.N. \& Nascimento, L.M. 2002. Levantamento florístico da floresta serrana da Reserva Biológica de Serra Negra, microrregião de Itaparica, Pernambuco. Brasil. Acta Botanica Brasilica 16: 481-500.

Rodal, M.J.N.; Sampaio, E.V.S. \& Figueiredo, M.A. 1992. Manual sobre métodos de estudos florísticos e fitossociológico - ecossistema caatinga. Sociedade Botânica do Brasil, Brasília. 24p.

Shepherd, G.J. 2006. Fitopac V. Universidade Estadual de Campinas, Campinas. 78p.

Whittaker, R.H. 1975. Communities and ecosystems. Macmillan, New York. 162p. 